\title{
THE ROLE OF MANAGERIAL EXPERIENCE IN THE MANAGEMENT EDUCATION PROCESS: STATUS, PROBLEMS, AND PROSPECTS
}

\author{
M. Ronald Buckley \\ Daniel A. Wren \\ Larry K. Michaelsen \\ University of Oklahoma
}

The recent work of Porter and McKibbin (1988) and the American Assembly of Collegiate Schools of Business (1991) has once again suggested a reassessment of the curricular requirements of the nation's business schools. Where have we failed in the past? Porter and McKibbin have reinforced the recent claim by Behrman and Levin (1984) that professors with narrow academic training and an inability to integrate functional disciplines bear the primary responsibility for the students who graduate with narrow viewpoints and training. Professors have been unable to develop their students' ability to think and act effectively when faced with the complexity of issues and pressures that typically face today's managers. The general argument that has been raised by critics is that the curricula of present-day business schools have become increasingly theoretical and reflect less and less the practical skills needed in day-to-day management activities. We would suggest that present-day management education is theoretical with a strong dose of rigor and an absence of relevance.

To ameliorate this problem, Porter and McKibbin (1988) reported that many of the respondents in their research suggested that business school professors should possess more "real world" managerial experience. It is

Authors'Note: The authors would like to thank the Noble Foundation of Ardmore, OK, for their support of this research. 
"strongly desireable for faculty to interact directly with the professional management community . . . most were agreed that this type of contact needed to be increased in the future" (p. 146). This echoed earlier contentions that increasing the managerial experience of professors was one incremental step in the improvement of business school curricula. Even the briefest exposure to the business world confirms that many business decisions are based on variables that are not (and, in some cases, cannot be) included in a rational business decision model. The result is that many business school graduates fail to get what they expect to receive from the organizations they join, nor do they progress at the rate they expected or hoped for (Livingston, 1973; Schein, 1964; Webber, 1976). Professors who are intermittently exposed to day-to-day managerial tasks may help to reduce the chasm associated with this expectations/reality gap by presenting a realistic view of what occurs in the business world. We believe that professors will be better able to fulfill their teaching mission when they are experienced in business practices. In addition, managerial experience will assist in focusing professors on the research needs of the business community. There is ample room in our disciplines for both applied and pure research. In fact, we believe that well-rounded faculties need to be proficient and experienced at both. Although pure research can exist in the absence of managerial experience and will advance our scientific disciplines, applied research in an environment that is not in touch with the business world is likely to be lacking in relevance. Thus we would suggest that managerial experience is essential in developing a proficient program of applied research. There is a danger, however, as pointed out by Porter and McKibbin (1988).

The real danger is that the pendulum will swing too much the other way and business school research will become very applied, but at a trivial level. In our opinion, it is better to have high-quality basic research that does not seem to have immediate applications than to have low-quality applied research that has pretensions of importance but in fact makes trifling contributions. (p. 308)

Overall, however, we would contend that intermittent managerial experience is a necessity for present-day professors and would result in increased research quality and significantly more current teaching content. Thus it would be of benefit to students in business schools and to other consumers of the product of our educational efforts.

Interestingly, the proposed new American Assembly of Collegiate Schools of Business (AACSB) standards for accreditation echo our suggestions that managerial experience is a necessary part of effective management instruction when it suggests that "business schools need mechanisms by which their faculty can observe business practices in action and thereby learn the appli- 
cability and relevance ... of new ideas and concepts developed in faculty intellectual activities ... . faculty need to spend time in organizations in significant interaction related to the phenomena about which they teach, perform research, and publish" (American Assembly of Collegiate Schools of Business, 1991)

Many critics have suggested that business school professors lack operational managerial experiences that are relevant and recent and thus are unable to instruct students in the optimal management techniques/skills/decisions. There may be a basis in fact for this contention. Over a decade ago, Wren, Atherton, and Michaelsen (1978, hereafter called "the 1977 study") investigated the amount of managerial experience possessed by the typical business school professor. They found that although the vast majority of the professors who were surveyed had only a modest amount of managerial experience (the modal response was 1-5 years), much of this experience was dated and in nonbusiness organizations and may have been only tangentially relevant to situations faced by managers of that time. What is today's situation? The purpose of this article is to investigate the managerial experience of management professors and a few of the contextual factors that may affect this important variable.

\section{Our Study}

Since the 1977 study, what changes have occurred in the managerial experience of those who teach and conduct research in our nation's colleges and universities? To investigate this question, we randomly surveyed members of the Academy of Management concerning their perceptions of the utility of managerial experience. Although they are not the total universe of individuals who teach management, we believe that they are representative of those who teach and conduct research in management. We sent out 2,000 questionnaires and received 622 responses, which yielded a return rate of $31 \%$. Of the 622 responses that were returned, 519 provided complete information and were included in the subsequent data analysis. The mean age of the respondents was 39.9 years. The highest degrees obtained were Ph.D., $85 \%$; master's, $13 \%$; and bachelor's, $2 \%$. With respect to recency of degrees, $18 \%$ were received in the past 5 years and $37 \%$ within the past 10 years. The mean for the year of the highest degree was 1977; the modal year was 1983. As to rank, $33 \%$ were full professors, $30 \%$ were associate professors, $28 \%$ were assistant professors, $6 \%$ were instructors, and $3 \%$ were graduate assistants. Seventy-eight percent were male; $22 \%$ were female. We compared the demographics of our respondents with the demographics of a recent survey 


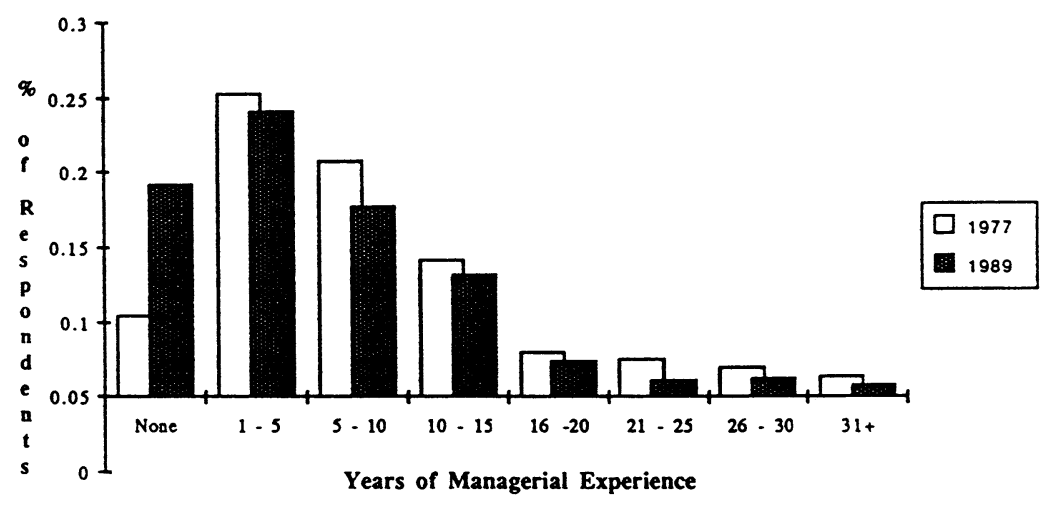

Figure 1: Total Managerial Experience of Management Faculty

of all Academy of Management members and concluded that our sample was representative of the academy.

\section{How Much Managerial Experience Do Professors Have?}

We found that the managerial experience of management professors has declined considerably since the data were first reported in 1977. As can be seen in Figure 1, all managerial experience levels have declined except in the category for those with no managerial experience. The number of management professors without managerial experience has almost doubled in percentage since the 1977 data were collected.

The idea that managerial experience has declined since the 1977 data were collected is reiterated in Figure 2, which illustrates the specific areas in which the decline of managerial experience has occurred since 1977. Apparently, according to this sample, the managerial experience of management professors has declined considerably since the Wren et al. survey was reported in the literature.

\section{Does Managerial Experience Facilitate Teaching and Research?}

To gain some insight into this issue, we asked our respondents, those who both teach and conduct research in management, the following two questions: 


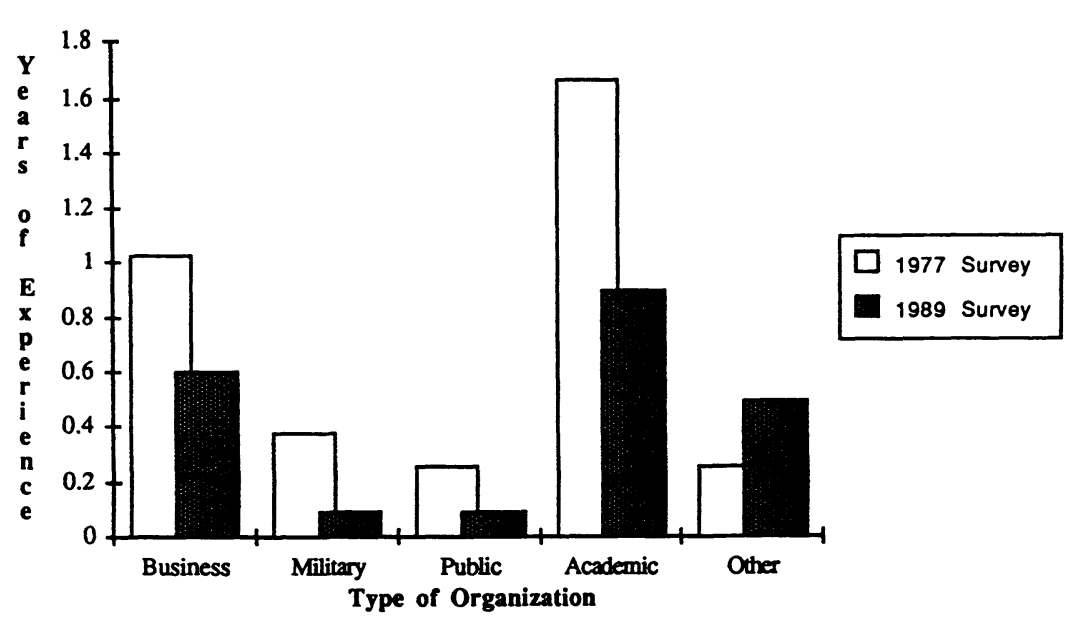

Figure 2: Comparison of Recent Managerial Experience of Management Faculty, 1977 Versus 1989

Question: To what extent do you believe that managerial experience does/would improve the quality of your research?

The respondents consistently indicated that managerial experience would be of some benefit to the quality of their research $(X=4.80 / 7$-pt. scale, $S D=.53)$.

Question: To what extent do you believe that managerial experience does/would improve the quality of your teaching?

The responses indicated that the respondents perceive that managerial experience would yield increases in the quality of instruction $(X=5.80 / 7$-pt. scale, $S D=.62)$. Managerial experience is perceived as being more helpful in terms of improving teaching quality, but it is also perceived, by the respondents, as being beneficial to research. It must be stressed that those who have managerial experience attach the most value to it (Wren, Buckley, \& Michaelsen, 1991). At least from the perspective of those who teach and conduct research in management, experience is perceived as an important contributor to their pursuits in both teaching and research.

\section{Support or Barriers to Acquiring Managerial Experience}

Professors believe that managerial experience will facilitate both their teaching and research skills. They perceive that administrators believe this 
to be so (but to a lesser extent). We also wanted to know if the administrative climate in the respondents' academic environments was conducive for professors' obtaining the management experience they believed was important, so we asked the respondents:

Question: To what extent do the administrators in your department/college believe that managerial experience improves/would improve the quality of your research?

The responses indicated that administrators are perceived as believing that managerial experience has a relatively small effect on the quality of research $(X=3.56 / 7$-pt. scale, $S D=.87$ ). This perception falls considerably short of the beliefs held by professors that managerial experience is of some benefit to research.

Question: To what extent do the administrators in your department/college believe that managerial experience improves/would improve the quality of your teaching?

The respondents indicated that they perceive that administrators believe that managerial experience would be somewhat helpful in improving the quality of teaching ( $X=4.83 / 7$-pt. scale, $S D=.58)$. This is similar to the opinion expressed by individual professors concerning their own beliefs about the importance of managerial experience.

Question: If you decided to invest a share of your time in gaining managerial experience, to what extent would your department/college administrators reward you?

The respondents indicated that the reward system does not facilitate efforts by individual professors to gain managerial experience $(X=2.32 / 7$-pt. scale, $S D=.76)$.

We also asked the respondents this question:

Question: To what extent do the administrators in your department/college provide you with opportunities to gain managerial experience?

The respondents indicated that seldom do administrators provide or search out opportunities for acquiring managerial experience $(X=2.23 / 7$-pt. scale, $S D=.89$ ). This may be because of the fear that professors might leave academia for better-paid positions in industry. 


\section{Why Schools Are Reluctant to Provide Opportunities to Gain Managerial Experience}

There are a number of reasons why schools fail to encourage and support faculty members who seek out managerial experience. One is that business school administrators are primarily concerned with "academic respectability." Academic respectability is a principal by-product of research and publication. Those schools that we think of as the better colleges of business are those schools with the better record in the area of research and publication. Thus administrators will reward research rather than (or in preference to) teaching excellence.

In addition, administrators might feel that encouraging contact with the business community might expose professors to such attractive consulting opportunities that they would be tempted to neglect their teaching and research responsibilities. We believe that, if consulting opportunities do not conflict with teaching and research responsibilities, they may well be helpful in the amelioration of the manifest deficit of managerial experience.

Furthermore, administrators may have a difficult time becoming directly involved in the developmental activities of faculty. There are at least two reasons for this: (a) Administrators are typically saddled with external constituents and internal responsibilities that make involvement difficult; (b) faculty may resent the intrusion into the individual operational level. After all, we pride ourselves as being internally motivated and knowledgeable concerning what we need to do.

\section{Removing Barriers to Obtaining Experience}

Perhaps we have mistakenly conceptualized the issue as one that is either-or, neglecting the fact that there are degrees of experience. It may be useful for faculty to spend some sabbatical time in industry, or it may be useful to have some faculty experience brief internships in industry. It may just be useful to give some faculty merely the opportunity to talk with people in industry. On the other hand we, in universities, need to elicit more participation from "industry leaders." This can be easily accomplished through, for example, soliciting industry input on college advisory boards as members or as "executives-in-residence" or by using industry people as adjunct professors to teach an occasional class or in the role of a guest 
speaker. Although adjunct professors are commonplace and do not typically interact with faculty, we suggest that they be co-opted as colleagues in curriculum design and research.

We are familiar with a situation currently developing at a major northeastern university, and we have heard of similar programs at numerous other universities. This university has recently received a pool of money that it has designated for faculty development. In the university's opinion, faculty development will have a more lasting effect than would a couple of scholarships given directly to students. Faculty at this university will write proposals requesting funds for internships in industry, sabbaticals in industry, field research, and other things that are related to enhancing the management experience of these professors. The only criterion is that such proposals be justified as applied business research or experience.

One of us (Michaelsen) has recently experienced a novel situation with the business community. He has just returned to the University of Oklahoma from a 2-year leave, during which time he worked full-time as a "scholar-inresidence" for a Fortune 100 company. As a full-fledged member of corporate management and executive development staff, he performed two different roles: (a) designing management and professional development courses and (b) coaching permanent training-staff members in the use of group-based instructional techniques. These experiences with practicing managers have served to enrich his classroom offerings. Michaelsen negotiated this experience on his own. This was, frankly, a risky career strategy. There are, however, other low-risk strategies for obtaining experience.

\section{Implications for the Future}

Are we teaching the optimal, skills-building curriculum in colleges of business? Many critics feel that we are not and that this is a significant contributory factor to the inability of American industry to successfully compete in the international marketplace. We would suggest that a large chasm has developed between what we teach in business schools and the knowledge that is necessary for success in a business-related career (see Buckley, Peach, \& Weitzel, 1989, for a discussion of this issue). This should come as no surprise because it has been bemoaned by authors for a considerable number of years. Most recently, a report issued by the Graduate Management Admission Council (GMAC, 1990) criticized the "pedantic sterility" that exists in our teaching and research and called for a new synthesis of "academic rigor and managerial relevance." GMAC (1990) reported further 
that today's business school faculties are "heavily homogenous ... white male, U.S. citizens trained in the social sciences and with limited managerial experience" (p. 27). Managerial experience was recommended as a means to develop the necessary synthesis between classroom knowledge and practice.

In our striving for academic excellence, we may have overemphasized the importance of publication over the quality of the instruction we give our clients. We have, to some extent, lost touch with our disciplines as they are (or should be) practiced in the business world.

\section{How Administrators Can Bring Experience Into the Curriculum}

What can be done to remedy this problem? We would like to make a number of suggestions that can be implemented by both classroom teachers and university administrators.

1. Managerial experience should be institutionalized as a part of doctoral education in business. This experience can be acquired before doctoral work begins or during the doctoral experience.

2. Corporations need to form partnerships with colleges of business. In addition to endowing prestigious research chairs in colleges of business, corporations should develop programs whereby professors can work in an industry for a period of time, with pay, either to gain managerial experience or to observe firsthand and see how corporations really operate.

3. "Academic respectability" needs to be broadened to include quality of teaching. University reward systems need to treat teaching and research success with a more even hand. Quality teaching is an academic pursuit. We advocate more than just an increased emphasis on teaching. Perhaps a significant evolution of the content of our teaching should also be considered.

4. More business involvement in colleges of business needs to be encouraged through vehicles such as advisory boards and through the support of executive-in-residence programs. In addition, businesses could provide easy access and encourage classroom visitations by practicing managers.

5. Colleges of business need to be convinced that it would be advantageous for students to be exposed to a qualified roster of adjunct faculty with appropriate academic credentials. But adjuncts need to do more than just teach courses where faculty are short. Adjunct professors should be incorporated into the faculty activities of research and curriculum design.

6. The "practitioner task force" within the Academy of Management should become more visible. We would also suggest that the professional interest groups in the Academy of Management should sponsor joint sessions 
with practitioners. Such sessions would serve to leaven the academic flavor with a bit of reality testing and to get the practitioner community more involved in the Academy of Management.

\section{How Classroom Teachers Can}

\section{Overcome a Lack of Managerial Experience}

1. Individual professors who do not have access to managerial experience should be encouraged to use the managerial experiences of the students who make up their classes. There are, almost without exception, students in class who have some degree of managerial experience. Their experiences need to be integrated into the framework of the course. For example, after explaining a management concept, it may be helpful to ask those students with managerial experience whether the concept was observed in their organization and if this concept has an effect on organizational effectiveness. This would be impossible to accomplish if a classroom teacher without managerial experience does all of the talking in class. Allow experienced students to participate.

2 . Get your students into the field. Give assignments that would necessitate interaction with practicing managers. Require that students interview management practitioners to perform a reality check of what is taught in class. Ask the students if there is a difference between what is taught in class and what transpires at work. If there is a difference, confront it and work through it.

3. Carefully select practitioners to invite to your class. It has been our experience that most management practitioners enjoy sharing their experience with students. After such a presentation, relate the principles you teach in class to the experiences that have been described by the management practitioner.

4. In the classroom, explicitly use information that indicates the broadranging applications of what is taught in class. Use articles from Business Week, Fortune, and the Wall Street Journal to illustrate management concepts.

5. Carefully select cases so that students can get involved in the solution to those cases in a personal and emotional way. Or, use films such as Norma Rae that explain important managerial concepts in an emotionally charged atmosphere.

6. You can create a "real organization" in the classroom. Basically, the class can become a functioning organization. This techniques serves to successfully illustrate the application of many of the management concepts about which we lecture. If you use groups in class, make sure all of the groups in class contain at least one member who has managerial experience. 


\section{A Final Warning to All}

Overall, we believe that this problem needs to be confronted as soon as possible. It has begged for solutions since the earliest reports assessing the lack of quality business education. The chasm has widened, and continued indifference to it will result in the institutionalization of the gap between what we teach students in business schools and what they need to know to function successfully in the business world.

\section{References}

American Assembly of Collegiate Schools of Business. (1991, April 23). Final report, the AACSB accreditation project. Unpublished manuscript, American Assembly of Collegiate Schools of Business, St. Louis, MO.

Behrman, J. N., \& Levin, R. I. (1984). Are business schools doing their job? Harvard Business Review, 62, 140-147.

Buckley, M. R., Peach, E. B., \& Weitzel, W. (1989). Are business programs adequately preparing students for the business world? Journal of Education for Business, 65, 101-105.

Graduate Management Admissions Council. (1990). Leadership for a changing world: The future role of graduate management education (Report of the Commission on Admissions to Graduate Management Education, Graduate Management Admissions Council). Los Angeles: Author.

Livingston, J. S. (1973). Myth of the well-educated manager. Harvard Business Review, 49, 79-99.

Porter, L. W., \& McKibbin, L. E. (1988). Management education and development: Drift or thrust into the 21st century? New York: McGraw-Hill.

Schein, E. H. (1964). How to break in the college graduate. Harvard Business Review, 42, 68-76.

Webber, R. A. (1976). Career problems of young managers. California Management Review, 18, 19-33.

Wren, D. A., Atherton, R. M., \& Michaelsen, L. K. (1978). The managerial experience of management professors: Are the blind leading the blind? Journal of Management, 4, 78-83.

Wren, D. A., Buckley, M. R., \& Michaelsen, L. K. (1991). The managerial experience of management professors: Are the blind still leading the blind? Manuscript submitted for publication. 